\title{
Sperm enter glands of preovulatory bovine endometrial explants and initiate inflammation
}

\author{
Ihshan Akthar ${ }^{1}$, Susan S Suarez ${ }^{2}$, Vernadyn A Morillo ${ }^{1,3}$, Motoki Sasaki ${ }^{1}$, Mohamed A Ezz ${ }^{1,4}$, \\ Ken-ichi Takahashi ${ }^{5}$, Masayuki Shimada ${ }^{6}$, Mohamed A Marey ${ }^{1,7}$ and Akio Miyamoto ${ }^{1}$ \\ ${ }^{1}$ Graduate School of Animal and Food Hygiene, Obihiro University of Agriculture and Veterinary Medicine, Obihiro, \\ Japan, ${ }^{2}$ Department of Biomedical Sciences, Cornell University, Ithaca, New York, USA, ${ }^{3}$ Department of Clinical \\ Sciences, College of Veterinary Medicine, Nueva Vizcaya State University, Nueva Vizcaya, Philippines, ${ }^{4}$ Department \\ of Theriogenology, Faculty of Veterinary Medicine, Mansoura University, Mansoura, Egypt, ${ }^{5}$ Genetics Hokkaido \\ Association, Shimizu-Cho, Japan, ${ }^{6} \mathrm{Graduate}$ School of Biosphere Science, Hiroshima University, Higashi-Hiroshima, \\ Japan and ${ }^{7}$ Department of Theriogenology, Faculty of Veterinary Medicine, Damanhur University, Behera, Egypt
}

Correspondence should be addressed to S S Suarez or A Miyamoto: sss7@cornell.edu or akiomiya@obihiro.ac.jp

\begin{abstract}
We previously reported that sperm binding to cultured monolayers of bovine uterine epithelial cells induces an acute inflammatory response involving the Toll-like receptor (TLR2) signaling pathway. This response serves to clear the uterus of sperm and thereby prepares the endometrium for implantation. The endometrium is lined by surface epithelial cells; however, epithelial cells also line uterine glands. To investigate the source of the immune response, we used an explant model. Explants of bovine endometrium were incubated with bull sperm illuminated by JC1 fluorescent labeling in their mitochondria. The sperm glided over the surface epithelium until they encountered and entered uterine glands, where they remained. Scanning electron microscopy of explants revealed polymorphonuclear neutrophils (PMNs) in uterine glands along with sperm. In the absence of sperm, PMNs were not seen in glands. The incubation of sperm with explants resulted in an acute inflammatory response, seen as the upregulation of mRNA expression of IL8, TNFA, IL1B, PGES and TLR2 in whole explants, as well as increased TNFA protein expression in uterine glands. TLR1/2 antagonist reduced sperm numbers in the glands and inhibited the increase of TNFA. Our observations suggest that uterine glands serve as a site where sperm interact with the uterine epithelium to trigger the innate immune response to clear excess sperm from the uterus.

Reproduction (2020) 159 181-192
\end{abstract}

\section{Introduction}

In the course of migrating through the female tract to the egg, mammalian sperm interact closely with the epithelium lining the tract (Suarez 2016, Dutta et al. 2019). Most work in the past 20 years has focused on the mammalian sperm interaction with the oviductal epithelium, which is important because the oviduct is the site of fertilization and the most common site of sperm storage (Suarez et al. 1997, Suarez 2002); however, the uterus also plays an important role in its interactions with sperm. That is, the uterus must clear sperm from its lumen as part of the preparation of uterus to receive embryos (Mattner 1968, Mitchell et al. 1985).

The removal of excess, defective and dead sperm from the uterus begins soon after insemination. In the cow, many sperm are removed rapidly after semen deposition through fluid backflow (Dobrowolski \& Hafez 1970, Suga \& Higaki 1971). In addition, the bovine uterus has a well-developed innate immune system that can mount an inflammatory response to sperm (Fair 2015) as well as to pathogens (Sheldon et al. 2019). The inflammatory response to sperm contributes to their rapid removal, which not only prepares the endometrium to receive an embryo but also prevents the development of acquired immune responses against sperm, that is, the production of anti-sperm antibodies that could reduce the fertility of the female (Zralý et al. 2003, Hansen 2011).

Bull sperm are rapidly removed during the inflammatory response mainly by polymorphonuclear neutrophils (PMNs) (Mattner 1968). The PMN influx after semen deposition is essential not only to remove sperm but also to remove pathogens that may be introduced during mating (Mattner 1968, Alghamdi et al. 2009). Influx of PMNs into the uterine lumen to remove sperm and pathogens has also been reported in horses (Katila 1995) and, pigs (Kaeoket et al. 2003). The elimination of sperm in the uterus by PMNs is mediated by two processes: phagocytosis of sperm and the formation of DNA-based neutrophil extracellular traps (Alghamdi et al. 2009, Hong et al. 2017). 
We recently reported that sperm binding to monolayer cultures of bovine uterine epithelial cells (BUECs) induces an acute inflammatory response in the epithelium (Elweza et al. 2018) by Toll-like receptor (TLR) signaling pathway via TLR2 (Ezz et al. 2019). However, in vivo, sperm interactions with the immunological defenses of the uterus could be mediated by the surface epithelium and/or glandular epithelium. Therefore, we adapted a bovine explant culture model (Borges et al. 2012) to investigate the site and dynamics of sperm interactions with the uterine epithelium under conditions that more closely resemble those in vivo. Our initial observations prompted us to hypothesize that sperm interact with the glandular epithelium of the preovulatory uterus to trigger immune responses. To test this hypothesis, we identified the site of sperm interactions using fluorescence video microscopy and scanning electron microscopy (SEM). Further, we evaluated the involvement of TLR2 in the sperm-uterine interaction and the inflammatory processes.

\section{Materials and methods}

All experiments described in this article were conducted in accordance with the relevant guidelines and regulation principles for the Care and Use of Research Animals Promulgated by Obihiro University of Agriculture and Veterinary Medicine, Japan. The Committee on the Ethics of Animal Experiments of the Obihiro University of Agriculture and Veterinary Medicine approved the protocol (Permit number 27-74).

\section{Reagents and media}

Chemicals were purchased from Wako Pure Chemical Industries, unless otherwise stated. A modified Tyrode balanced salt solution, Tyrode albumin lactate pyruvate (TALP) (Parrish et al. 1988), was used for washing and diluting sperm and for incubating endometrial explants with sperm. TALP consisted of $99 \mathrm{mM} \mathrm{NaCl}, 3.1 \mathrm{mM} \mathrm{KCl}, 25 \mathrm{mM} \mathrm{NaHCO}$, $0.39 \mathrm{mM} \mathrm{NaH}{ }_{2} \mathrm{PO}_{4}, 10 \mathrm{mM}$ HEPES-free acid, $2 \mathrm{mM} \mathrm{CaCl}{ }_{2}$, $1.1 \mathrm{mM} \mathrm{MgCl} 2,25.4 \mathrm{mM}$ sodium lactate, $0.11 \mathrm{mg} / \mathrm{ml}$ sodium pyruvate, $5 \mu \mathrm{g} / \mathrm{ml}$ gentamycin and $6 \mathrm{mg} / \mathrm{ml} \mathrm{BSA} \mathrm{pH} \mathrm{7.4.}$ TALP was equilibrated in a $38.5^{\circ} \mathrm{C}$ incubator (bovine core body temperature) with $5 \% \mathrm{CO}_{2}$ in humidified air before use. Saline was used as a transport medium for uterine horns and consisted of $154 \mathrm{mM} \mathrm{NaCl}, 10 \mu \mathrm{g} / \mathrm{mL}$ penicillin-streptomycin (Gibco) and $10 \mu \mathrm{g} / \mathrm{mL}$ amphotericin B (Gibco) pH 7.4.

\section{Animals and tissue preparation}

Uterine samples of cows were collected from the local slaughterhouse (Hokkaido Livestock, Doto Plant Tokachi Factory, Obihiro, Hokkaido, Japan). The reproductive tracts were trimmed free of surrounding tissues, opened and macroscopically examined to be free from pus, inflammation and abnormal color. The phase of the estrous cycle was identified based on the appearance, weight and color of the corpus luteum and the follicular diameter according to a protocol described previously (Wijayagunawardane et al. 1998). The ipsilateral horns relative to the ovary containing the mature follicle of the preovulatory phase (days 19-22) and those relative to the ovary containing the acute corpus luteum of the luteal phase (days 10-12) were isolated and transported on ice-cold saline to the laboratory. Then, the uterine horns were incised longitudinally. Endometrial explants were prepared according to a method described previously (Borges et al. 2012) with modifications. Using an $8 \mathrm{~mm}$ biopsy punch (Kai industries, Oyana, Japan), disks of endometrial tissue were dissected from the glandular (intercaruncular) endometrial regions (Atkinson et al. 1984). Then, surgical scissors were used to dissect approximately $2 \mathrm{~mm}$ intact endometrium from the underlying tissue. Explants were immediately placed, epithelial surface up, in a glass petri dish filled with TALP and kept at $38.5^{\circ} \mathrm{C}$ by a temperature-controlled micro warm plate (KM-2, Kitazato, Japan). A coating of clear mucus could be seen on the surface epithelium of the explants. The explants were incubated in a $38.5^{\circ} \mathrm{C}$ incubator with $5 \% \mathrm{CO}_{2}$ in humidified air for 15 min before experiments were initiated. Normal tissue architecture and the viability of the explants were confirmed using hematoxylin and eosin (HE) tissue sections (Borges et al. 2012) and Caspase 3 mRNA expression (Zhang et al. 2018).

\section{Sperm sample preparation}

Fresh semen samples of highly fertile Holstein bulls were obtained from Genetics Hokkaido Association, Hokkaido, Japan. Fresh semen was immediately diluted in egg-yolk extender $(1: 1)$ in a $15 \mathrm{ml}$ tube. The tube was maintained in a temperature-controlled heat jacket $\left(15^{\circ} \mathrm{C}\right)$ during transport to the laboratory $(1 \mathrm{~h})$. Then the semen was maintained in $15^{\circ} \mathrm{C}$ until the beginning of the experiment $(6 \mathrm{~h})$. The choice of storage of extended semen at $15^{\circ} \mathrm{C}$ for transport was based on reports by Murphy et al. (2015) and testing at $4^{\circ} \mathrm{C}$ and $22^{\circ} \mathrm{C}$. Immediately prior to the experiment, sperm were washed by diluting $2 \mathrm{~mL}$ extended semen with $3 \mathrm{~mL}$ TALP, centrifuging at $170 \mathrm{~g}$ for $10 \mathrm{~min}\left(25^{\circ} \mathrm{C}\right)$, resuspending the pellet in $5 \mathrm{~mL}$ TALP and repeating the centrifugation twice. The resulting sperm pellet was resuspended in TALP. Sperm concentration was determined using a hemacytometer (C-chip, NanoEnTek, Korea) and adjusted to $10^{6} \mathrm{sperm} / \mathrm{mL}$ for incubation with endometrial explants. Heat-inactivated sperm were prepared by the incubation of washed fresh sperm in a water bath at $56^{\circ} \mathrm{C}$ for 30 min (Kodithuwakku et al. 2007).

\section{Incubation of sperm with bovine endometrial explants}

To investigate the time-dependent response of endometrial explants to sperm, preovulatory phase explants were incubated with $10^{6} \mathrm{sperm} / \mathrm{mL}$ for $0,0.5$ and $2 \mathrm{~h}$ in a $38.5^{\circ} \mathrm{C}$ incubator with $5 \% \mathrm{CO}_{2}$ in humidified air using 24 well plates with $0.5 \mathrm{~mL}$ TALP/ well. This sperm concentration had previously been shown to stimulate innate immune responses in monolayer cultures of BUECs (Elweza et al. 2018, Ezz et al. 2019). Explants without sperm served as controls for each time point. To investigate the effect of heat-inactivated sperm, the preovulatory phase explants were incubated with $10^{6}$ heat-inactivated sperm $/ \mathrm{mL}$ for $2 \mathrm{~h}$. To 
investigate the effect of sperm, the luteal phase explants were incubated with $10^{6} \mathrm{sperm} / \mathrm{mL}$ for $2 \mathrm{~h}$. Explants without sperm served as controls. The involvement of the TLR2 in sperm-uterine attachment and the inflammatory process was examined using TLR1/2 antagonist-CU-CPT22 (Merck) (Cheng et al. 2012). The preovulatory phase explants were pre-incubated with $1 \mu \mathrm{M}$ antagonist in a $38.5^{\circ} \mathrm{C}$ incubator with $5 \% \mathrm{CO}_{2}$ in humidified air for $30 \mathrm{~min}$. Then the explants were incubated with $10^{6} \mathrm{sperm} /$ $\mathrm{mL}$ for $2 \mathrm{~h}$. Explants without antagonist and sperm served as controls. All experiments were repeated five times using endometrial explants from five different uteri (three wells per treatment per experiment). Explants were collected and washed three times in TALP and stored in TRIZOL (Invitrogen), at $-80^{\circ} \mathrm{C}$ until total RNA extraction.

\section{JC1 labeling of sperm}

To see the sperm on the epithelial surface of explants, the sperm were stained with the mitochondrial stain JC1 (AdipoGen, San Diego, CA, USA). For this approach, $0.5 \mathrm{~mL} 10^{6} \mathrm{sperm} / \mathrm{mL}$ were pre-incubated with $6.4 \mu \mathrm{M} \mathrm{JC1}$ in a $38.5^{\circ} \mathrm{C}$ incubator with $5 \%$ $\mathrm{CO}_{2}$ in humidified air for 15 min, directly before adding them to explants. It was not necessary to wash labeled sperm before adding them to explants, because the dilution of the JC1 dye in the explant culture medium provided us with helpful faint images of the epithelial surfaces without obscuring the view of sperm.

\section{Observation of sperm behavior after incubation with endometrial explants}

To visualize the behavior of sperm on endometrial explants, JC1-labeled sperm were incubated with explants for $5 \mathrm{~min}$ and $30 \mathrm{~min}$. To evaluate the effect of TLR1/2 antagonist on sperm behavior, the preovulatory phase endometrial explants were pre-incubated with $1 \mu \mathrm{M}$ TLR1/2 antagonist in a $38.5^{\circ} \mathrm{C}$ incubator with $5 \% \mathrm{CO}_{2}$ in humidified air for $30 \mathrm{~min}$. Then JC1labeled sperm were incubated with pre-incubated explants for $30 \mathrm{~min}$. Explants without antagonist served as controls. Endometrial explants were oriented as epithelial surface uppermost. In order to see the sperm, each explant was rinsed through wells containing $38.5^{\circ} \mathrm{C}$ TALP and transferred to a well that contained $0.5 \mathrm{~mL} 38.5^{\circ} \mathrm{C}$ TALP; the explants were oriented as epithelial surface downward on the heated stage of the inverted microscope. Sperm behavior in endometrial explants was viewed using an all-in-one fluorescence microscope (Keyence, BZ-X800, Osaka, Japan) equipped with a temperature-controlled thermal plate (TPi-SQX, Tokai Hit, Japan). Videos and images were taken using the BZ-X TexasRed (OP-87765) and BZ-X GFP (OP-87763) filters set for red and green wavelengths respectively. During the video recording, the focus was adjusted to count and visualize all sperm that entered and remained in the glands and sperm on the surface epithelium.

\section{Determination of the numbers of sperm in uterine glands}

Videos (JC1-labeled sperm) recorded at 30 min of explants with sperm \pm antagonist were assessed for numbers of sperm in uterine glands. Recorded videos were converted to gray scale, and contrast was optimized in the same way on all videos using Image (Version 1.51j8) before counting sperm. Counts were made of three glands of equal size in each experimental treatment.

\section{Histology and immunohistochemistry}

To investigate the effect of sperm on the preovulatory phase endometrium, the explants were incubated with $10^{6} \mathrm{sperm} /$ $\mathrm{mL}$ for $4 \mathrm{~h}$. Explants without sperm served as controls. The experiment was repeated four times using endometrial explants from four different uteri. Explants were gently rinsed in TALP and fixed in $10 \%$ formalin in phosphate buffer (PB) ( $\mathrm{pH} \mathrm{7.4).}$ After $24 \mathrm{~h}$, the fixed tissue samples were transferred to $70 \%$ ethanol and then dehydrated in a graded series of ethanol, cleared in xylene, embedded in paraffin and cut serially in $4 \mu \mathrm{m}$ thick slices. The endometrial sections were placed on an aminopropyl-triethoxy-silane-coated slides (S8226, Matsunami Glass Int., Osaka, Japan) and deparaffinized. The sections were stained with HE for the observation of general histology and immunohistochemically stained using the avidin-biotin-peroxidase complex (ABC) method. Briefly, the sections were treated by microwave in target retrieval solution (1:10, S1699; Dakocytomatin, CA, USA) for 15 min and then immersed in methanol containing $0.3 \% \mathrm{H}_{2} \mathrm{O}_{2}$ for $10 \mathrm{~min}$ at room temperature (RT) to block endogenous peroxidase activity. Afterward, the sections were incubated with normal goat serum (1:50, S-1000, Vector Laboratories, CA, USA) for $30 \mathrm{~min}$ at RT to reduce nonspecific staining and incubated overnight with mouse monoclonal anti-bovine tumor necrosis factor-alpha primary antibody $(1: 400,2.5 \mu \mathrm{g} /$ $\mathrm{ml}, \mathrm{MCA} 2334$, Bio-Rad) at $4^{\circ} \mathrm{C}$ in a humidified chamber. After being incubated with the primary antibody, the sections were incubated with biotinylated goat anti-mouse $\lg$ (1:200, 7.5 $\mu \mathrm{g} / \mathrm{ml}, \mathrm{BA}-9200$, Vector Laboratories) for $30 \mathrm{~min}$, and then $A B C$ reagent was applied for 30 min (1:2, PK-6100, Vectastain Elite ABC kit, Vector Laboratories). The binding sites were visualized with Tris- $\mathrm{HCl}$ buffer $(\mathrm{pH} 7.4)$ containing $0.02 \%$ $3,3^{\prime}$-diaminobenzidine hydrochloride (DAB) and $0.006 \%$ $\mathrm{H}_{2} \mathrm{O}_{2}$. After incubation, the sections were washed with 0.01 $\mathrm{M}$ phosphate-buffered saline (PBS, pH 7.4) and the nuclei was counterstained with hematoxylin. Slides were dehydrated in a graded series of ethanol, cleared in xylene, cover slipped and observed with a conventional light microscope (Nikon, Microphot-FX), and images were obtained (Nikon, Digital Sight DS-SM). The negative control sections omitted the primary antibody. HE-stained sections were observed using an all-in-one fluorescence microscope (Keyence, BZ-X800).

\section{Immunofluorescence analysis}

Endometrial sections were fixed and blocked as described earlier, followed by incubation overnight at $4{ }^{\circ} \mathrm{C}$ with mouse monoclonal anti-bovine tumor necrosis factor-alpha primary antibody (1:400, $2.5 \mu \mathrm{g} / \mathrm{ml}$, MCA2334, Bio-Rad). The sections were then stained with DAPI $(1: 50,340-07971$, Dojindo Laboratories, Japan) for $30 \mathrm{~min}$ followed by labeling with the secondary antibody $(1: 200,5 \mu \mathrm{g} / \mathrm{ml}$ goat anti-mouse 
IgG labeled with Alexa Fluor, Invitrogen, Thermo Fisher Scientific) for $30 \mathrm{~min}$. Sections were washed, and coverslips were mounted using VECTASHIELD mounting medium (H-1000; Vector Laboratories). The fluorescence signal was then captured using an all-in-one fluorescence microscope (Keyence, BZ-X800) using the BZ-X GFP (OP-87763) and BZ-X DAPI (OP-87762) filters set for green and blue wavelengths respectively. Exposure time was kept constant for the primary antibody and its negative antibody control.

\section{Isolation of PMNs from blood}

PMNs were isolated from whole bovine blood from three animals according to a protocol described previously (Marey et al. 2014). Heparinized blood was collected from a Holstein cow and mixed with an equal volume of PBS, then gently layered over Ficoll-Paque solution (Lymphoprep, Axis-Shield, Oslo, Norway) and centrifuged at $1000 \mathrm{~g}$ for $30 \mathrm{~min}$ at $10^{\circ} \mathrm{C}$. Then the PMN layer was mixed with ammonium chloride lysis buffer (155 $\mathrm{mM} \mathrm{NH}_{4} \mathrm{Cl}, 3.4 \mathrm{mM} \mathrm{KHCO}$ and 96.7 $\mu \mathrm{M}$ EDTA) for $10 \mathrm{~s}$ and centrifuged at $500 \mathrm{~g}$ for $10 \mathrm{~min}$ at $10^{\circ} \mathrm{C}$ to purify $\mathrm{PMN}$ from red blood cells. Finally, the isolated PMNs were washed twice with PBS.

\section{Scanning electron microscopy}

The preovulatory phase endometrial explants and $10^{6}$ cells/ $\mathrm{mL}$ washed fresh sperm were incubated for $30 \mathrm{~min}$ and prepared for SEM. Explants without sperm served as controls. To evaluate the effects of TLR1/2 antagonist on sperm entering uterine glands, the preovulatory phase explants were preincubated with $1 \mu \mathrm{MTLR} 1 / 2$ antagonist in a $38.5^{\circ} \mathrm{C}$ incubator with $5 \% \mathrm{CO}_{2}$ in humidified air for $30 \mathrm{~min}$. Then the explants were incubated with $10^{6}$ cells $/ \mathrm{mL}$ sperm for $30 \mathrm{~min}$. Explants without TLR1/2 antagonist treatment served as controls. Both of these experiments were repeated two times using endometrial explants from two different uteri. Explants were gently washed in TALP and fixed in PB 10\% formalin.

Isolated PMNs were placed on a cover glass coated with $0.1 \%$ neoprene in toluene, dried at RT and fixed in $2.5 \%$ glutaraldehyde in 0.1 M PB. After fixation, the samples were washed in PBS, post-fixed in 1\% osmium tetroxide in PBS and dehydrated in a graded series of ethanol. The specimens were then freeze-dried with t-butyl alcohol using a freeze dryer (ES-2030; Hitachi High-Technologies, Tokyo, Japan). The dried samples were mounted on stubs and sputter coated with Pt using an ion sputter (E-1045; Hitachi High-Technologies, Tokyo, Japan). The samples were observed using a scanning electron microscope (S3400N; Hitachi High-Technologies) at an accelerating voltage of $5 \mathrm{kV}$.

\section{Isolation of RNA and analysis of mRNA by quantitative real-time $P C R$}

Endometrial explants were homogenized in TRIZOL reagent using an ultrasonic processor (Sonics and Materials, CT, USA) under ice-cold conditions, and further total RNA extraction was performed using TRIZOL reagent according to a protocol described previously (Chomczynski \& Sacchi 1987). The concentration and purity of extracted RNA were determined using NanoDrop Spectrophotometer (2000c, Thermo Scientific) by the absorbance at $260 \mathrm{~nm}$ and the $260 / 280 \mathrm{~nm}$ ratios respectively. After measurements, the RNA was stored at $-80^{\circ} \mathrm{C}$ in the RNA storage solution (Ambion, Austin, TX, USA) until cDNA synthesis.

The cDNA was synthesized following a protocol described previously (Yousef et al. 2016) with minor modifications. First, a DNase treatment step was performed using RQ1 RNase-free DNase kit (Promega) to remove residual genomic DNA and other contaminants through which $1 \mu \mathrm{g}$ extracted RNA was incubated for $30 \mathrm{~min}$ at $37^{\circ} \mathrm{C}$ in a thermal cycler (Eppendorf, Hamburg, Germany) with a first mixture consisting of $1 \mu$ RQ1 RNase-free DNase, $10 \times$ reaction buffer, $2 \mu \mathrm{l}$ RQ1 RNase-free DNase and nuclease-free water (Invitrogen) to a final volume of $10 \mu \mathrm{l}$, followed by the addition of $1 \mu \mathrm{l}$ RQ1 DNase Stop solution for $10 \mathrm{~min}$ at $65^{\circ} \mathrm{C}$ to terminate the reaction. After that, the first-strand cDNA was synthetized according to the

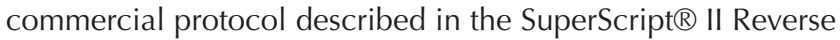
Transcriptase kit (Invitrogen). Simply, the DNase-treated RNA was incubated at $65^{\circ} \mathrm{C}$ for $5 \mathrm{~min}$ with a second mixture Consisting of $1.5 \mu \mathrm{l}$ of $3 \mu \mathrm{g} / \mu \mathrm{l}$ random primer, $1.5 \mu \mathrm{l} 10 \mathrm{mM}$ PCR nucleotide mix (dNTP) (Roche Diagnostics) and nucleasefree water to a final volume of $18 \mu \mathrm{l}$. In this sequence, a third mixture consisting of $6 \mu \mathrm{l}$ of $5 \times$ first-strand buffer, $3 \mu$ of $0.1 \mathrm{M}$ dithiothreitol and $1.5 \mu \mathrm{l}$ of 40 units/ $\mu$ l Ribonuclease Inhibitor Recombinant (Toyobo, Osaka, Japan) was added per each tube and then incubated at $42^{\circ} \mathrm{C}$ for $2 \mathrm{~min}$, followed by the addition

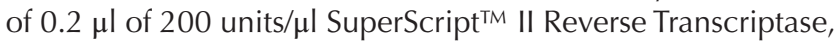
and the thermal cycler was programmed at $25^{\circ} \mathrm{C}$ for $10 \mathrm{~min}$, $42^{\circ} \mathrm{C}$ for $50 \mathrm{~min}$ and then $70^{\circ} \mathrm{C}$ for $15 \mathrm{~min}$. The synthesized cDNA was stored at $-30^{\circ} \mathrm{C}$.

Quantitative real-time PCR was carried out by a MiniOpticon (Bio-Rad Laboratories) using SYBR Green PCR Master Mix (Bio-Rad Laboratories). Simply, a total $10 \mu \mathrm{l}$ reaction mix consisting of $2 \mu \mathrm{l} /$ sample synthesized cDNA, 5 $\mu \mathrm{l}$ QuantiTect SYBR Green PCR Master Mix (Qiagen), $0.2 \mu \mathrm{l}$ of the targeted primer pairs (Table 1 ) and $2.8 \mu$ l nuclease-free water (Invitrogen) was prepared. The amplification program was run with an initial activation step $\left(15 \mathrm{~min}\right.$ at $\left.95^{\circ} \mathrm{C}\right)$, followed by 40 cycles of PCR $\left(15 \mathrm{~s}\right.$ denaturation at $95^{\circ} \mathrm{C}$, $15 \mathrm{~s}$ annealing at $55-58^{\circ} \mathrm{C}$ and $30 \mathrm{~s}$ extension at $72^{\circ} \mathrm{C}$ ). A negative control, reactions containing nuclease-free water or non-reverse transcribed RNA, was incubated in each run. The primer pairs were designed by Primer Express ${ }^{\circledR}$ Software v3.0.1 (Thermo Scientific). The melting curve was evaluated at the end of the run to observe the specificity of the amplification. The calculated cycle threshold $(\mathrm{Ct})$ values were normalized using $\mathrm{B}$-actin as an internal control. Fold changes in relative mRNA expression were determined using the Delta-Delta comparative threshold method (Livak \& Schmittgen 2001). The housekeeping gene, $\beta$-actin, was used as an internal standard for the normalization of Ct values because its mRNA expression was stable in all experiments; no significant variations were observed in its mRNA expression across the different treatments. 
Table 1 List of the primers used in real-time PCR.

\begin{tabular}{|c|c|c|c|c|}
\hline \multirow[b]{2}{*}{ Gene } & \multicolumn{2}{|c|}{ Sequence of nucleotide $\left(5^{\prime} \rightarrow 3^{\prime}\right)$} & \multirow[b]{2}{*}{ Accession no. } & \multirow[b]{2}{*}{ Fragment size $(b p$} \\
\hline & Forward & Reverse & & \\
\hline$\beta$-Actin & TCACCAACTGGGACGACATG & CGTTGTAGAAGGTGTGGTGCC & NM_173979.3 & 51 \\
\hline IL8 & CCAATGGAAACGAGGTCTGC & ССТTCTGСАСССАСТTTTССТ & NM_173925.2 & 51 \\
\hline TNFA & CAAAAGCATGATCCGGGATG & TTCTCGGAGAGCACСТCСТC & NM_173966.3 & 51 \\
\hline$I L 1 B$ & AATCGAAGAAAGGCCСGTCT & ATATCCTGGCCACCTCGAAA & NM_174093.1 & 51 \\
\hline PGES & AAAATGTACGTGGTGGCCGT & СТTCTTCCGСAGССТСАСТT & NM_174443.2 & 51 \\
\hline TLR2 & CATGGGTCTGGGCTGTCATC & ССTGGTCAGAGGCTCСTTCC & NM_174197.2 & 51 \\
\hline
\end{tabular}

\section{Statistical analysis}

GraphPad Prism 5 software (GraphPad Software) was used for statistical analysis. Student's $t$-test was applied to compare the mean differences between two groups, and one-way ANOVA followed by Tukey's tests was used to compare the mean differences for more than two groups. Each experiment was repeated five times using explants from different cows. Each group has three replicates, and all the individual values were pooled and used for statistical analysis. All values are presented as mean \pm S.E.M. Data were considered to be statistically significant at $* P<0.05,{ }^{*} * P<0.01, * * * P<0.001$.

\section{Results}

\section{Uterine glands are intact in preovulatory bovine endometrial explants}

In the fresh explants of intercaruncular endometrium, a thick, clear layer of mucus could be seen on the surface epithelium. The mucus was viscoelastic and could not be removed by washing the explants in medium.

The histological sections of explants stained with HE showed normal tissue architecture (Fig. 1A). The surface epithelial layer was intact, and uterine glands were present throughout the endometrium. The tubular uterine glands maintained the normal structure
(Fig. 1A and B). SEM images of whole explants clearly show the funnel-shaped entrance into a uterine gland (Fig. 1C).

\section{Sperm glided over the surface epithelium of explants and entered uterine glands}

As early as $5 \mathrm{~min}$ after the addition of sperm to preovulatory explants, fluorescence video microscopy of sperm with JC-1-stained midpieces revealed that the sperm glided over the surface epithelium until they encountered a uterine gland. There, they stopped within the funnel-shaped opening of the gland, while their flagella continuing beating (Video 1). Next, we used autofluorescence microscopy to see motile sperm within glands after $30 \mathrm{~min}$ incubation of sperm with explants (Fig. 2A and Video 2). In this video, the glands are viewed at a slight angle, such that sperm within the glands can be seen clearly. Both videos showed sperm in all visible glands.

\section{Video 1.}

JC-1 stained mitochondria in sperm midpieces illuminate sperm that glide over the endometrial surface 5 min after the addition of the sperm to a preovulatory
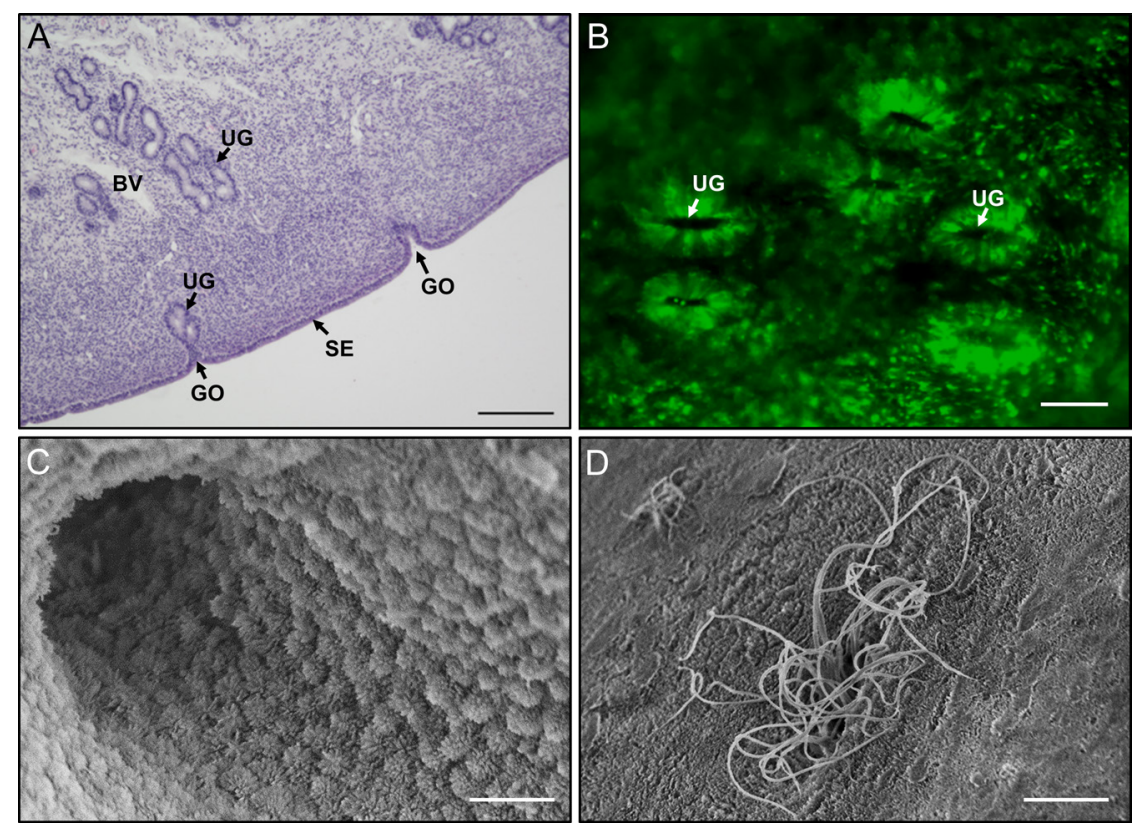

Figure 1 (A) A section of an endometrial explant stained with haematoxylin and eosin (HE) shows the uterine glands (UGs) in the endometrium. SE, surface epithelium, GO, gland opening, BV, blood vessels. Bar $=200$ $\mu \mathrm{m}$. (B) A fluorescence image shows the presence of UGs in an unstained endometrial explant, revealing autofluorescence under a BZ-X GFP (OP-87763) filter set. Bar $=100 \mu \mathrm{m}$. (C) SEM micrograph shows the funnel-shaped UG opening to the uterine lumen. Bar $=5 \mu \mathrm{m}$. (D) Sperm appear only within or on the rims of UGs and not attached to the surface epithelium. Sperm tails are visible in the UGs. Bar $=10 \mu \mathrm{m}$. 

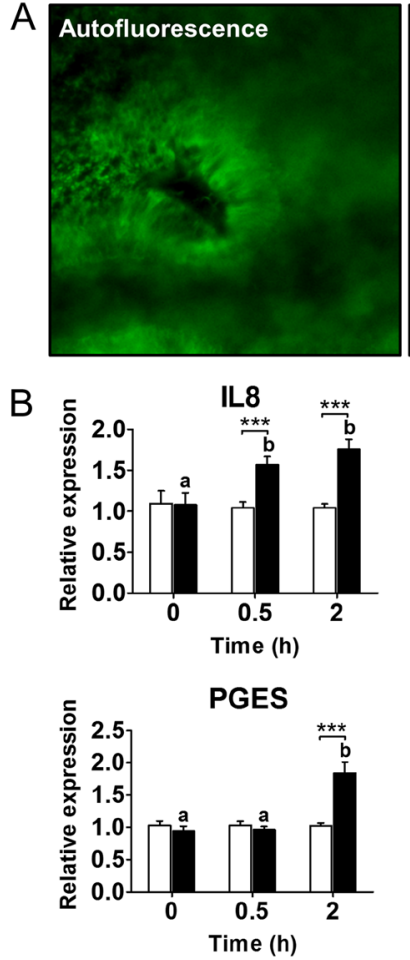

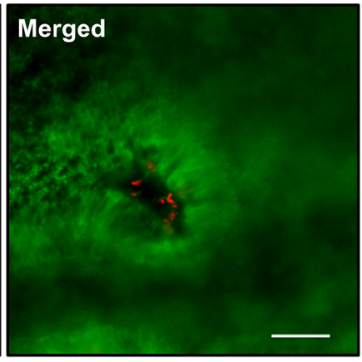

TNFA
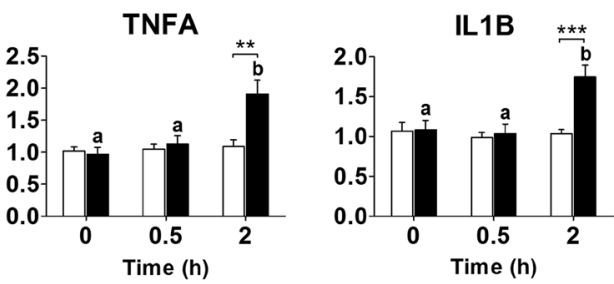

TLR2

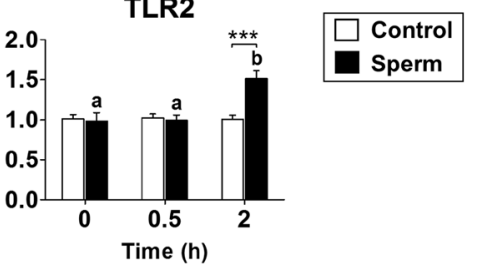

Figure 2 (A) JC1-stained midpiece mitochondria of sperm within the preovulatory phase uterine glands after 30 min incubation with explants of preovulatory endometrium. Bars $=50 \mu \mathrm{m}$. (B) Time-dependent effect of sperm on the relative mRNA expression of proinflammatory cytokines, PGES and TLR2 in the preovulatory bovine endometrial explants. Explants had been incubated with $10^{6}$ sperm/ $\mathrm{mL}$ for $0,0.5$ and $2 \mathrm{~h}$. Data are presented as mean \pm S.E.M. of five independent experiments. Three uterine explants from one cow were used in each experiment. ${ }^{* *} P<0.01$,

$* * * P<0.001$ denote significant difference (control versus sperm group at the same time point). Different letters denote a significant difference $(P<0.05)$ for the sperm groups compared at different time points. endometrial explant. Sperm can be seen stopping at the openings of two glands that are side by side at the left side and center of the video. This was due to the binding of the heads to the epithelial surface of the funnel-shaped entrance of the glands (Fig. 1C). The fluorescence video was taken using BZ-X TexasRed (OP-87765) filter set and then converted to gray scale using ImageJ (version 1.51j8). The video (http://movieusa.glencoesoftware.com/video/10.1530/REP-19-0414/ video-1) from the online version of the article is available at https://doi.org/10.1530/REP-19-0414.

\section{Video 2.}

Thirty minutes after the addition of sperm to an explant, the beating of the tails of sperm held within two glands can be seen. The fluorescence video was taken using BZ-X GFP (OP-87763) filter set to see autofluorescence and then converted to grayscale using ImageJ (version 1.51j8). This is why sperm heads and the epithelial lining of the glands can be seen in this video. The video (http:// movie-usa.glencoesoftware.com/video/10.1530/REP19-0414/video-2) from the online version of the article is available at https://doi.org/10.1530/REP-19-0414.

SEM revealed greater details of the sperm and glands. The heads of sperm within glands were in contact with the glandular epithelium (Fig. 3A) and/or other sperm (Fig. 3B) and the tails protruded from the glandular openings into the uterine lumen (Fig. 1D). Sperm appeared to associate with microvilli in the glandular cells (Fig. 3A). Occasionally, a ciliated epithelial cell could be seen near or in glands, but sperm were not found associated with the cilia.

\section{PMNs appeared in the glandular lumen among the sperm}

After sperm entered the glands, additional cells were seen in the glands among the clusters of sperm (Fig. 3A). The cells (Fig. 3B) were identified as PMNs, because their size and morphology were identical to PMNs isolated from bovine blood (Fig. 3C). Some PMNs appeared to bind to sperm (Fig. 3B). Neither PMNs nor other nonepithelial cells were seen in the glands in the absence of sperm (Fig. 1C).

\section{Sperm upregulated mRNA expression in the preovulatory explants}

Incubation of sperm with preovulatory endometrial explants for only 30 min resulted in an increase in interleukin 8 (IL8), which is a strong chemokine for PMNs. IL8 expression increased throughout the $2 \mathrm{~h}$ co-incubation $(P<0.05)$ (Fig. $2 \mathrm{~B})$. Co-incubation for $2 \mathrm{~h}$ also resulted in the significant upregulation of the proinflammatory cytokines tumor necrosis factoralpha (TNFA) and interleukin 1-beta (IL1B), as well as increases in prostaglandin E synthase (PGES) and TLR2 mRNA expression.

At 30 min uterine explant incubation with heatinactivated sperm, no sperm were seen within uterine 

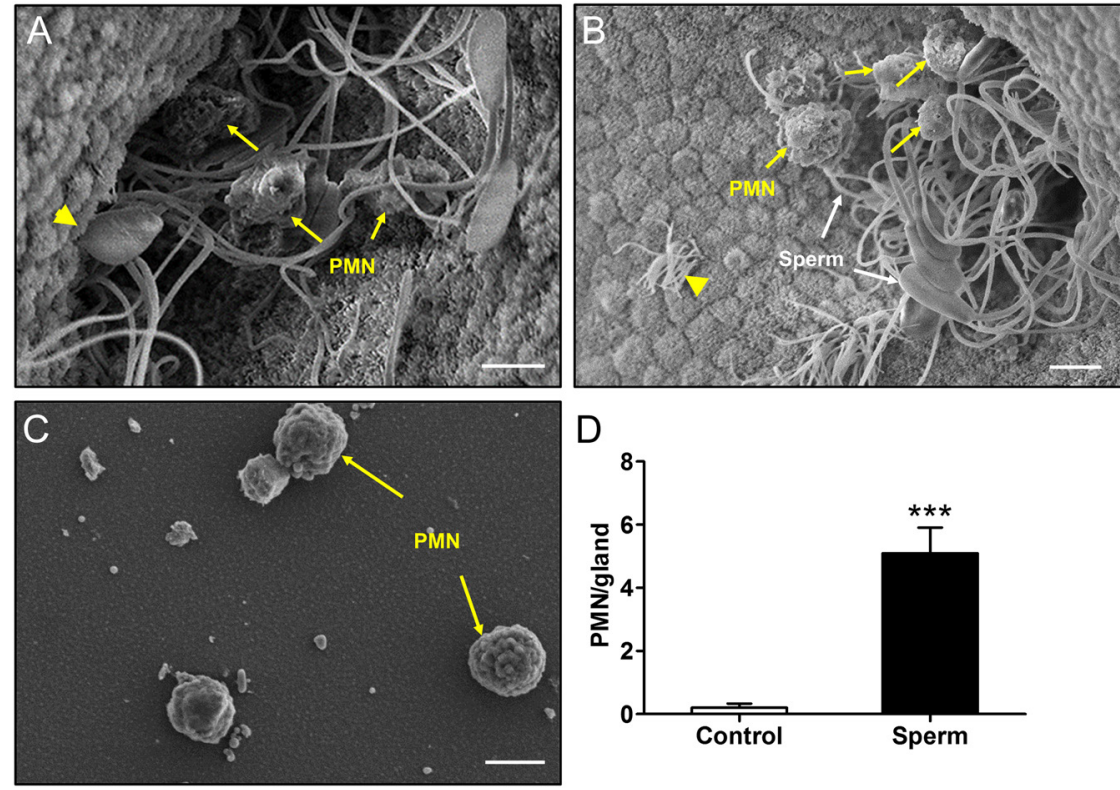

D

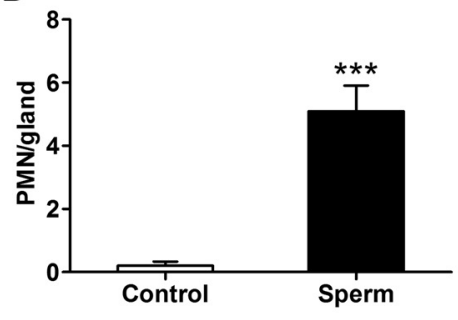

Figure 3 Scanning electron microscopy (SEM). The preovulatory phase endometrial explants were incubated with $10^{6} \mathrm{sperm} / \mathrm{mL}$ for $30 \mathrm{~min}$ and prepared for SEM. (A) PMNs and sperm within a UG. Note that sperm are attached to the glandular epithelial cells (arrowhead). Bar $=5 \mu \mathrm{m}$. (B) PMNs binding to sperm at the opening of a UG. Note that a single ciliated surface epithelial cell can be seen (arrowhead); the remainder of the surface epithelial cells show microvilli on their apical surfaces. Bar $=5 \mu \mathrm{m}$. (C) Bovine PMNs collected from blood. Bar $=5 \mu \mathrm{m}$. (D) Mean \pm S.E.M. number of PMNs per UG in endometrial explants incubated for $30 \mathrm{~min}$ with and without sperm. Data are presented as mean \pm S.E.M. of two independent experiments. Ten glands were counted per each group. ${ }^{* * *} P<0.001$ denote a significant difference.

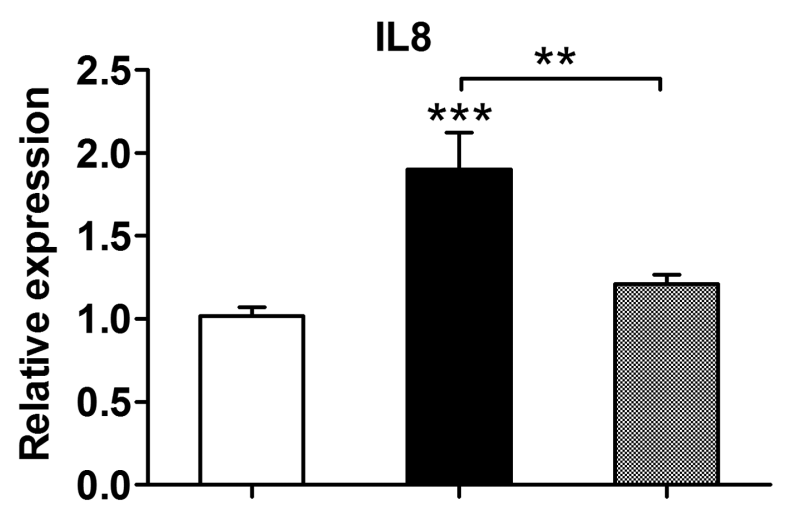

TNFA

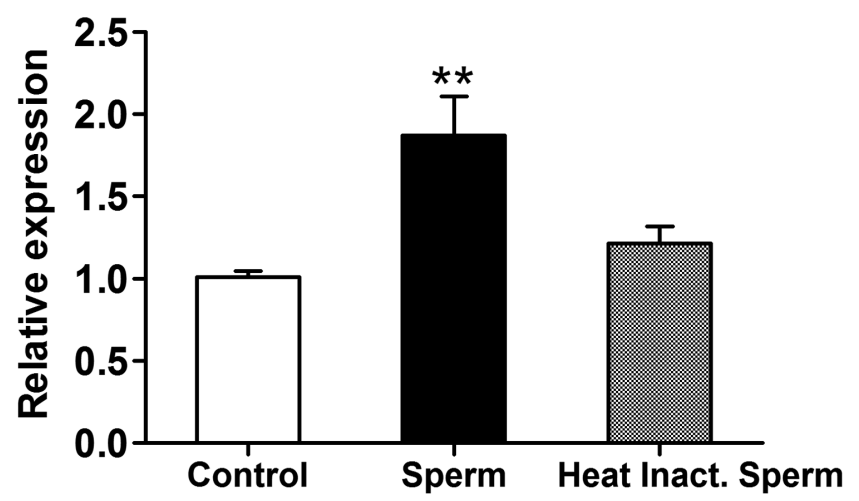

Figure 4 Relative mRNA expression of IL 8 and TNFA in preovulatory phase bovine endometrial explants incubated with $10^{6} \mathrm{cells} / \mathrm{mL}$ of fresh sperm, fresh heat-inactivated sperm and without (control) sperm for 2 h. Data are presented as mean \pm S.E.M. of five independent experiments. Three endometrial explants from individual cow were used in each experiment. ${ }^{* *} P<0.01,{ }^{* * *} P<0.001$ denote significant difference. glands. Moreover, heat-inactivated sperm did not affect the mRNA expression of IL8 or TNFA (Fig. 4).

When live, motile sperm were incubated with luteal phase endometrial explants, the sperm did not appear to enter the glands. Furthermore, the sperm did not alter the mRNA expression of IL8, TNFA or ILIB in the luteal phase explants (Fig. 5). It should be noted that sperm were seen attaching to the extracellular matrix of the connective tissue on the basal surface of the explants. In vivo, sperm would not normally encounter this connective tissue, which would not be exposed at the surface of the endometrium. We eliminated the possibility that this interaction of sperm with connective tissue was an initiator of the changes in mRNA expression we observed, because mRNA expression changed only with the exposure of preovulatory explants to sperm, in which sperm entered the glands, and not when luteal explants were exposed to sperm, in which sperm did not enter glands.

\section{Sperm upregulated TNFA protein expression in uterine glands}

TNFA protein expression was detected using both immunofluorescence and immunohistochemical staining. Both staining methods showed that, when sperm were incubated with uterine explants for $4 \mathrm{~h}$, sperm upregulated TNFA expression in uterine glands (Fig. 6A and B).

\section{TLR2 antagonist reduced sperm numbers in glands and inhibited gene expression}

SEM images (Fig. 7A) and fluorescence video microscopy revealed that the addition of TLR1/2 antagonist prior to adding sperm subsequently reduced the sperm numbers 

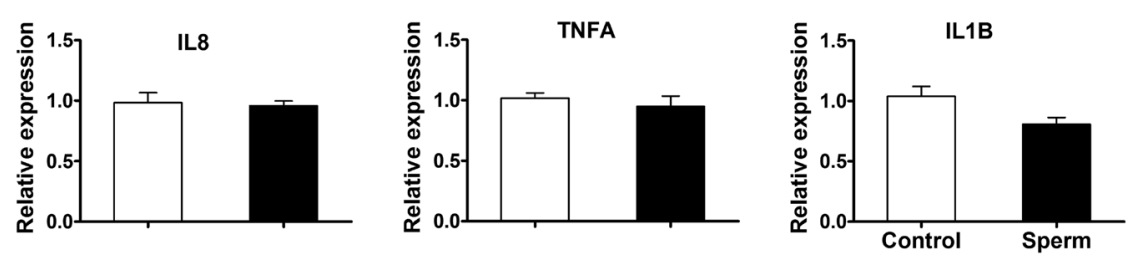

Figure 5 Relative mRNA expression of proinflammatory cytokines in luteal phase bovine endometrial explants incubated with $10^{6} \mathrm{sperm} / \mathrm{mL}$ and without (control) sperm for $2 \mathrm{~h}$. Data are presented as mean \pm S.E.M. of five independent experiments. Three endometrial explants from individual cow were used in each experiment.

in the glands $(P<0.001)$ (Fig. $7 \mathrm{~B})$ and inhibited the increase of TNFA gene expression seen in the presence of sperm (Fig. 8). The treatment of preovulatory explants with TLR1/2 antagonist alone for $2 \mathrm{~h}$ did not change the gene expression of IL8, TNFA, or ILIB in the explants (Fig. 9).

\section{Discussion}

Our explant culture model provided the first direct visual evidence that sperm glide over the endometrial surface and enter uterine glands. Both the videos of fluorescently labeled sperm and the SEM images demonstrated that sperm did not bind to the surface epithelium of the endometrial explants, but they entered and were held in the glands. The mucous layer on the surface epithelium may have enabled the sperm to glide smoothly over the epithelial cells until sperm came into contact with the openings of uterine glands. Further, due to the established hydrodynamics of sperm nearsurface swimming, bull sperm would be expected to remain swimming along the surface epithelium (i.e. not swimming away from the surface) and to enter the glands when they were encountered (Denissenko et al. 2012,
Tung et al. 2015). The SEM images indicate that sperm within the glands attach to microvilli of the glandular epithelium, which may be part of the mechanism that held sperm within the glands.

Sperm retention in the uterine glands has been reported in many mammalian species, such as guinea pig, stoat, hedgehog, mole (Austin 1960), dog (Doak et al. 1967), sow (Lovell \& Getty 1968), rabbit (Koyama et al. 1986) and bat (Racey et al. 1987). However, to our knowledge, there are no reports of studies that link sperm retention in glands with uterine immune responses. Therefore, ours is the first report that sperm in uterine glands stimulate innate immune responses.

Our SEM images indicated that sperm bound by their heads to the glandular epithelium, as well as to each other. Furthermore, sperm entrapment in the glands seemed to be strong, because sperm were retained in glands after washing the explants. This observation is supported by a previous study, where many more sperm were detected in the canine uterus by histology and SEM than by uterine flushing, indicating that sperm were held tightly in uterine glands (Rijsselaere et al. 2004). Glandular retention of sperm has been shown in the histological sections of bovine uterine glands $24 \mathrm{~h}$ after

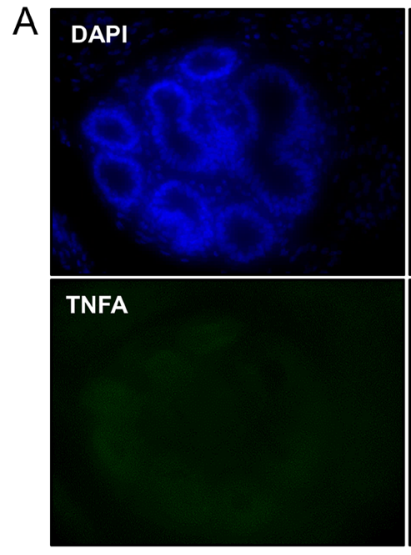

Without Sperm

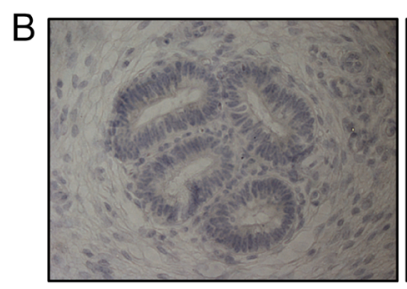

Without Sperm

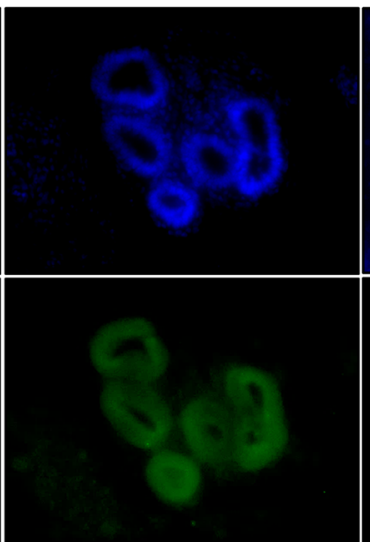

With Sperm

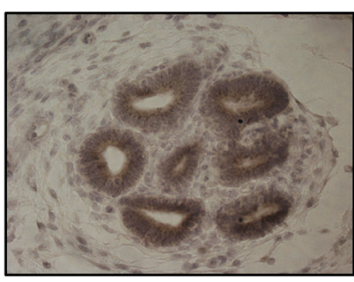

With Sperm

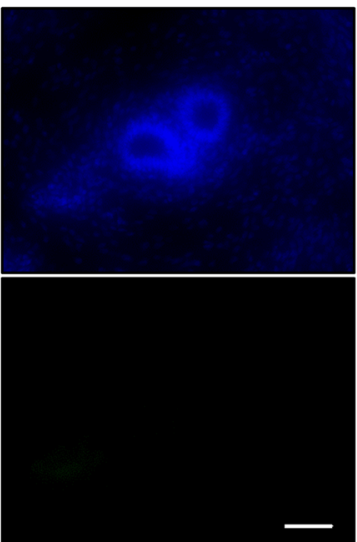

Negative Control

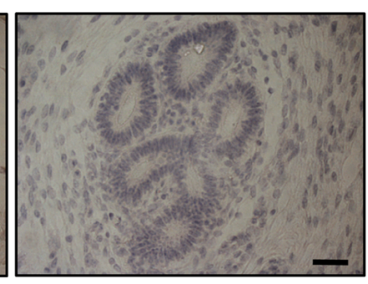

Negative Control
Figure 6 TNFA expression in endometrial explants, particularly in uterine glands after the incubation of bovine uterine explants for 4 $\mathrm{h}$ with and without sperm using (A) immunofluorescence labeling with Alexa Fluor-conjugated anti-TNFA antibody, and (B) immunostaining with peroxidase-conjugated anti-TNFA antibody, visualized using DAB (brown). The primary antibody was omitted in the negative control sections. Nuclei are counterstained with hematoxylin. Bars $(A)=50$ $\mu \mathrm{m},(\mathrm{B})=20 \mu \mathrm{m}$. 

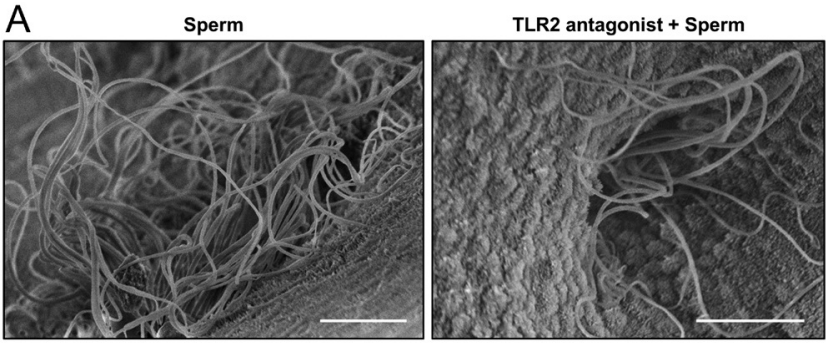

B

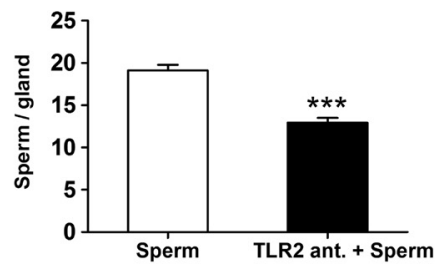

Figure 7 TLR2 antagonist reduced sperm numbers in uterine glands. (A) SEM images of bovine endometrial explants that had been incubated with sperm \pm TLR1/2 antagonist. The preovulatory phase endometrial explants were pre-incubated with $1 \mu \mathrm{M} \mathrm{TLR} 1 / 2$ antagonist for $30 \mathrm{~min}$, followed by the addition of sperm and incubation for an additional $30 \mathrm{~min}$. Bars $=10 \mu \mathrm{m}$. (B) Number of sperm/gland in explants incubated with sperm \pm TLR1/2 antagonist. Data are presented as mean \pm S.E.M. of five independent experiments. For each treatment, sperm were counted in three uterine glands. ${ }^{* * *} P<0.001$ denote a significant difference.

Al (Koyama et al. 1986), indicating that sperm retention lasts for several hours in vivo.

The percentage of sperm retained in the glands was low when compared to total sperm added. We estimated roughly $0.5 \%$ of the sperm added to the explant culture wells were trapped in the glands. This calculation was based on the numbers of sperm added to the wells, the mean number of glands per explant and the mean numbers of sperm counted within representative glands. Nevertheless, because the physical dimensions of the uterine lumen and endometrial surface are different from the physical dimensions of our explant model with $8 \mathrm{~mm}$ endometrial tissue disks, it is not possible to extrapolate our data to the percentage of sperm that enter glands in vivo.

Our data indicate that sperm interaction with the glandular epithelium triggers local uterine innate immune responses via the upregulation of proinflammatory cytokines. Sperm upregulated mRNA expression of proinflammatory cytokines IL8 (at $0.5 \mathrm{~h}$ ) and TNFA and ILIB (at $2 \mathrm{~h}$ ) in whole explants. Previously, our group reported that frozen-thawed motile sperm upregulated similar genes in BUECs, in which the uterine epithelium was somewhat dedifferentiated and epithelium could not be distinguished from the glandular epithelium (Elweza et al. 2018). Further, in the present study, we detected the synthesis of TNFA protein, a strong proinflammatory marker, in the glandular epithelium. Our immunohistochemistry results indicated that TNFA protein was expressed mainly in the glandular
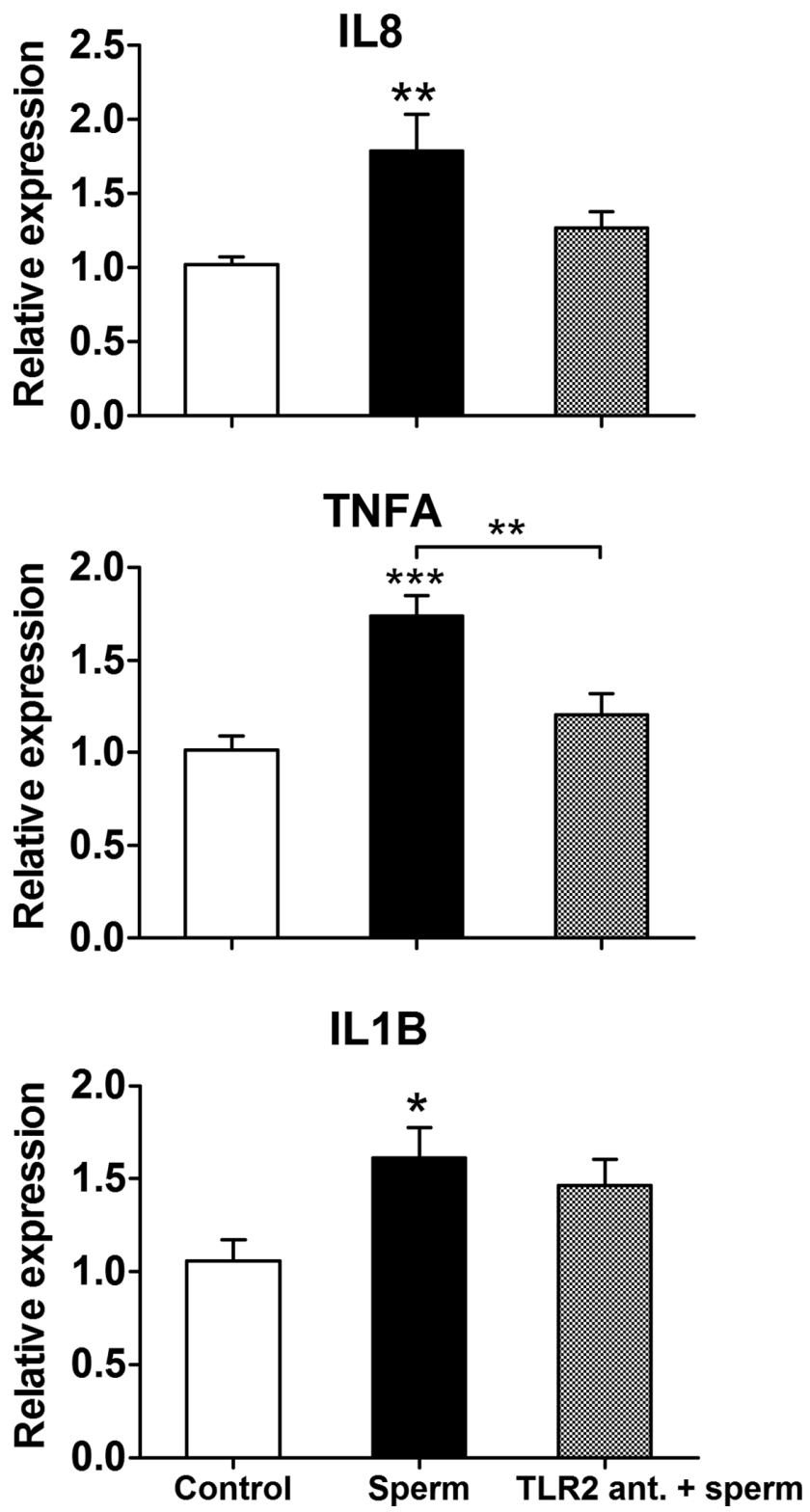

Figure 8 Relative mRNA expression of proinflammatory cytokines in preovulatory phase explants incubated with sperm, with sperm +TLR1/2 antagonist and without sperm or antagonist for $2 \mathrm{~h}$. Data are presented as mean \pm S.E.M. of five independent experiments. Three explants from individual cows were used in each experiment. ${ }^{*} P<0.05,{ }^{* *} P<0.01,{ }^{* * *} P<0.001$ denote significant difference.

epithelium. We cannot completely exclude the possibility that luminal epithelium is also involved in the inflammatory response, as mRNA expression was measured in the whole explant. Nevertheless, it should be noted that most of the sperm we observed in vitro glided over the mucus-coated endometrial surface rather than adhering to endometrial cells. These observations suggest that sperm entering glands is one of the main triggers of the uterine immune response, if not the only one. Further investigations are necessary to clarify the 

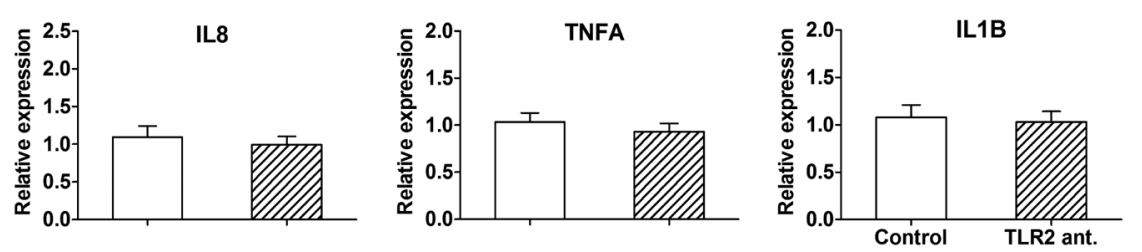

Figure 9 Relative mRNA expression of proinflammatory cytokines in preovulatory phase explants incubated with \pm TLR1/2 antagonist for $2 \mathrm{~h}$. Data are presented as mean \pm S.E.M. of five independent experiments. Three explants from individual cows were used in each experiment. ${ }^{*} P<0.05,{ }^{*} * P<0.01$, *** $P<0.001$ denote significant difference. role of luminal epithelium in activating the inflammatory cascade induced by sperm.

Our SEM images showed that PMNs were present in the glands. PMNs are known to rapidly enter the uterine lumen after the insemination of cows (Alghamdi et al. 2009), as well as of females of several other species of mammals (Mattner 1968, Katila 1995, Rozeboom et al. 1998, England et al. 2013). Our experiments indicate that, in the case of cattle, the initial route of PMNs into the uterine cavity is from glands. The source of the PMNs would be the endometrial stroma, which was present in our explants. It has been reported that, during pro-estrus and estrus in cattle, PMNs assemble in large numbers in the endometrial stroma (Mattner 1968). After PMNs enter the glands, attachment of sperm to PMNs could upregulate the innate immune response by triggering the $\mathrm{PMNs}$ to produce immune-regulatory cytokines, which can, in turn, increase additional PMN migration, including additional migration through the surface epithelium.

The PMNs in the bovine uterine glands could phagocytize sperm. PMNs have been observed phagocytizing uterine sperm in other species such as in mice, rats (Austin 1957), goats (Mattner 1968), pigs (Pursel et al. 1978), and rabbits (Bedford 1965). PMN phagocytosis of sperm within uterine glands was reported in little brown bats, guinea pigs, horseshoe bats, rabbits and pigs (Austin 1960, Koyama et al. 1986, Racey et al. 1987). In addition to PMNs, there is some evidence that macrophages phagocytize sperm within uterine glands in rabbits and cows (Koyama et al. 1986). Altogether, phagocytosis within the glands and the uterine lumen is thought to clear sperm from the uterus in preparation for the arrival and implantation of embryos (Katila 2012).

Our observations revealed that sperm entered and remained in the preovulatory phase uterine glands but not luteal phase glands. It seemed that fewer sperm were gliding over the surface epithelium of luteal endometrium; however, the sperm that were seen did not enter into the glands they encountered. In the luteal phase, under progesterone dominance, uterine glands are known to become enlarged, tortuous and full of secretion (Ohtani et al. 1993, Wahab et al. 1999, Dhaliwal et al. 2002, Wang et al. 2007). Although the physical attraction of sperm for surfaces would tend to direct them into glands, as discussed earlier, the physical and/or chemical nature of the luteal phase secretions in the glands may have prevented them from doing so.
Previously we reported that the addition of CU-CPT22, a TLR1/2 antagonist (Cheng et al. 2012), into BUEC monolayer cultures suppressed the proinflammatory response of BUECs to sperm and the phosphorylation of JNK as a downstream target of the TLR2 signaling pathway (Ezz et al. 2019). To check the involvement of TLR2 in the explant response to sperm, we tested the effects of the antagonist on explant response to sperm. Pre-incubation of uterine explants with antagonist reduced sperm retention in the uterine glands and prevented the increased expression of the inflammatory cytokine TNFA. Further investigations are necessary to elucidate the detailed mechanism of the activation of TLR2 signaling pathway by sperm.

It can be concluded that our bovine explant culture model can be used to investigate the initial spermuterine interactions and immune responses. Here, the culture model provided evidence that sperm entry into uterine glands triggers the innate immune response. A next step would be to determine whether this initial response in the glands eventually leads to a massive immigration of PMNs into the stroma and then through the surface epithelium to the uterine cavity to ensure that the cavity is thoroughly cleared and prepare for the arrival of the embryo.

\section{Declaration of interest}

The authors declare that there is no conflict of interest that could be perceived as prejudicing the impartiality of the research reported.

\section{Funding}

The present research work was funded by a Grant-in-Aid for Scientific Research (16H05013, 17 F17407 and 18K19259) of Japan Society for the Promotion of Science (JSPS), Kieikai Research Foundation (2018C015 and 2019C055) and in part by Livestock Promotional Funds of Japan Racing Association (JRD).

\section{Author contribution statement}

I A, S S S, M S $\mathrm{S}^{6}$ and $A M$ conceived and designed the experiments; I A, S S S, V A M, M S $1, M A E$ and $M A M$ performed the experiments; I A, S S S, V A M, M A E and M A $M$ analyzed the data; $M S^{1}, K T$ and $A M$ provided reagents/ 
materials/analysis tools; and I A, S S S, M S ${ }^{6}$ and A M wrote the manuscript. All authors reviewed the manuscript.

\section{Acknowledgements}

We thank Anni Nurliani, Veterinary Anatomy, Obihiro University, Japan, for her help in immunocytochemistry and scanning electron microscopy.

\section{References}

Alghamdi AS, Lovaas BJ, Bird SL, Lamb GC, Rendahl AK, Taube PC \& Foster DN 2009 Species-specific interaction of seminal plasma on sperm-neutrophil binding. Animal Reproduction Science 114 331-344. (https://doi.org/10.1016/j.anireprosci.2008.10.015)

Atkinson BA, King GJ \& Amoroso EC 1984 Development of the caruncular and intercaruncular regions in the bovine endometrium. Biology of Reproduction 30 763-774. (https://doi.org/10.1095/biolreprod30.3.763)

Austin CR 1957 Fate of spermatozoa in the uterus of the mouse and rat. Journal of Endocrinology 14 335-342. (https://doi.org/10.1677/ joe.0.0140335)

Austin CR 1960 Fate of spermatozoa in the female genital tract. Reproduction 1 151-1NP. (https://doi.org/10.1530/jrf.0.0010151)

Bedford JM 1965 Effect of environment on phagocytosis of rabbit spermatozoa. Journal of Reproduction and Fertility 9 249-256. (https:// doi.org/10.1530/jrf.0.0090249)

Borges AM, Healey GD \& Sheldon IM 2012 Explants of intact endometrium to model bovine innate immunity and inflammation ex vivo. American Journal of Reproductive Immunology 67 526-539. (https://doi. org/10.1111/j.1600-0897.2012.01106.x)

Cheng K, Wang X, Zhang S \& Yin H 2012 Discovery of small-molecule inhibitors of the TLR1/TLR2 complex. Angewandte Chemie $\mathbf{5 1}$ 12246-12249. (https://doi.org/10.1002/anie.201204910)

Chomczynski P \& Sacchi N 1987 Single-step method of RNA isolation by acid guanidinium thiocyanate-phenol-chloroform extraction. Analytical Biochemistry 162 156-159. (https://doi.org/10.1006/abio.1987.9999)

Denissenko P, Kantsler V, Smith DJ \& Kirkman-Brown J 2012 Human spermatozoa migration in microchannels reveals boundary-following navigation. PNAS 109 8007-8010. (https://doi.org/10.1073/ pnas.1202934109)

Dhaliwal GS, Murray RD, Rees EM, Howard CV \& Beech DJ 2002 Quantitative unbiased estimates of endometrial gland surface area and volume in cycling cows and heifers. Research in Veterinary Science $\mathbf{7 3}$ 259-265. (https://doi.org/10.1016/s0034-5288(02)00098-x)

Doak RL, Hall A \& Dale HE 1967 Longevity of spermatozoa in the reproductive tract of the bitch. Journal of Reproduction and Fertility $\mathbf{1 3}$ 51-58. (https://doi.org/10.1530/jrf.0.0130051)

Dobrowolski W \& Hafez ESE 1970 Transport and distribution of spermatozoa in the reproductive tract of the cow. Journal of Animal Science 31 940-943. (https://doi.org/10.2527/jas1970.315940x)

Dutta S, Aoki K, Doungkamchan K, Tiemeyer M, Bovin N \& Miller DJ 2019 Sulfated lewis A trisaccharide on oviduct membrane glycoproteins binds bovine sperm and lengthens sperm lifespan. Journal of Biological Chemistry 294 13445-13463. (https://doi.org/10.1074/jbc. RA119.007695)

Elweza AE, Ezz MA, Acosta TJ, Talukder AK, Shimizu T, Hayakawa $H$, Shimada M, Imakawa K, Zaghloul AH \& Miyamoto A 2018 A proinflammatory response of bovine endometrial epithelial cells to active sperm in vitro. Molecular Reproduction and Development 85 215-226. (https://doi.org/10.1002/mrd.22955)

England GCW, Russo M \& Freeman SL 2013 The bitch uterine response to semen deposition and its modification by male accessory gland secretions. Veterinary Journal 195 179-184. (https://doi.org/10.1016/j. tvjl.2012.04.027)

Ezz MA, Marey MA, Elweza AE, Kawai T, Heppelmann M, Pfarrer C, Balboula AZ, Montaser A, Imakawa K, Zaabel SM et al. 2019 TLR2/4 signaling pathway mediates sperm-induced inflammation in bovine endometrial epithelial cells in vitro. PLOS ONE 14 e0214516. (https:// doi.org/10.1371/journal.pone.0214516)
Fair T 2015 The contribution of the maternal immune system to the establishment of pregnancy in cattle. Frontiers in Immunology 67. (https://doi.org/10.3389/fimmu.2015.00007)

Hansen PJ 2011 The immunology of early pregnancy in farm animals. Reproduction in Domestic Animals 46 18-30. (https://doi.org/10.1111/ j.1439-0531.2011.01850.x)

Hong J, Dicker BL, Jayasinghe SN, De Gregorio F, Tian H, Han DY \& Hudson KR 2017 Strong inhibition of neutrophil-sperm interaction in cattle by selective phosphatidylinositol 3-kinase inhibitors. Biology of Reproduction 97 671-687. (https://doi.org/10.1093/biolre/iox121)

Kaeoket K, Persson E \& Dalin AM 2003 Influence of pre-ovulatory insemination and early pregnancy on the distribution of CD2, CD4, CD8 and MHC class II expressing cells in the sow endometrium. Animal Reproduction Science 76 231-244. (https://doi.org/10.1016/s03784320(02)00240-3)

Katila T 1995 Onset and duration of uterine inflammatory response of mares after insemination with fresh semen. Biology of Reproduction 52 515517. (https://doi.org/10.1093/biolreprod/52.monograph_series1.515)

Katila T 2012 Post-mating inflammatory responses of the uterus. Reproduction in Domestic Animals 47 31-41. (https://doi.org/10.1111/ j.1439-0531.2012.02120.x)

Kodithuwakku SP, Miyamoto A \& Wijayagunawardane MPB 2007 Spermatozoa stimulate prostaglandin synthesis and secretion in bovine oviductal epithelial cells. Reproduction 133 1087-1094. (https://doi. org/10.1530/REP-06-0201)

Koyama H, Tsutsumi Y \& Suzuki H 1986 Observations on sperm penetration into the uterine gland of the rabbit, sow and cow. Japanese Journal of Zootechnical Science $\mathbf{5 7}$ 512-523.

Livak KJ \& Schmittgen TD 2001 Analysis of relative gene expression data using real-time quantitative PCR and the $2-\Delta \Delta C T$ method. Methods 25 402-408. (https://doi.org/10.1006/meth.2001.1262)

Lovell JW \& Getty R 1968 Fate of semen in the uterus of the sow: histologic study of endometrium during the 27 hours after natural service. American Journal of Veterinary Research 29 609-625.

Marey MA, Liu J, Kowsar R, Haneda S, Matsui M, Sasaki M, Takashi S, Hayakawa H, Wijayagunawardane MPB, Hussein FM et al. 2014 Bovine oviduct epithelial cells downregulate phagocytosis of sperm by neutrophils: prostaglandin E2 as a major physiological regulator. Reproduction 147 211-219. (https://doi.org/10.1530/REP-13-0375)

Mattner PE 1968 The distribution of spermatozoa and leucocytes in the female genital tract in goats and cattle. Journal of Reproduction and Fertility 17 253-261. (https://doi.org/10.1530/jrf.0.0170253)

Mitchell JR, Senger PL \& Rosenberger JL 1985 Distribution and retention of spermatozoa with acrosomal and nuclear abnormalities in the cow genital tract. Journal of Animal Science 61 956-967. (https://doi. org/10.2527/jas1985.614956x)

Murphy C, Holden SA, Murphy EM, Cromie AR, Lonergan P \& Fair S 2015 The impact of storage temperature and sperm number on the fertility of liquid-stored bull semen. Reproduction, Fertility, and Development 28 1349-1359. (https://doi.org/10.1071/RD14369)

Ohtani S, Okuda K, Nishimura K \& Mohri S 1993 Histological changes in bovine endometrium during the estrous cycle. Theriogenology 39 1033-1042. (https://doi.org/10.1016/0093-691x(93)90004-o)

Parrish JJ, Susko-Parrish J, Winer MA \& First NL 1988 Capacitation of bovine sperm by heparin. Biology of Reproduction 38 1171-1180. (https://doi.org/10.1095/biolreprod38.5.1171)

Pursel VG, Schulman LL \& Johnson LA 1978 Distribution and morphology of fresh and frozen-thawed sperm in the reproductive tract of gilts after artificial insemination. Biology of Reproduction 19 69-76. (https://doi. org/10.1095/biolreprod19.1.69)

Racey PA, Uchida TA, Mori T, Avery MI \& Fenton MB 1987 Spermepithelium relationships in relation to the time of insemination in little brown bats (Myotis lucifugus). Journal of Reproduction and Fertility $\mathbf{8 0}$ 445-454. (https://doi.org/10.1530/jrf.0.0800445)

Rijsselaere T, Van Soom A, Van Cruchten S, Coryn M, Görtz K, Maes D \& de Kruif A 2004 Sperm distribution in the genital tract of the bitch following artificial insemination in relation to the time of ovulation. Reproduction 128 801-811. (https://doi.org/10.1530/rep.1.00273)

Rozeboom KJ, Troedsson MH \& Crabo BG 1998 Characterization of uterine leukocyte infiltration in gilts after artificial insemination. Journal of Reproduction and Fertility 114 195-199. (https://doi.org/10.1530/ jrf.0.1140195) 
Sheldon IM, Cronin JG \& Bromfield JJ 2019 Tolerance and innate immunity shape the development of postpartum uterine disease and the impact of endometritis in dairy cattle. Annual Review of Animal Biosciences 7 361-384. (https://doi.org/10.1146/annurev-animal-020518-115227)

Suarez SS 2002 Formation of a reservoir of sperm in the oviduct. Reproduction in Domestic Animals 37 140-143. (https://doi. org/10.1046/j.1439-0531.2002.00346.x)

Suarez SS 2016 Mammalian sperm interactions with the female reproductive tract. Cell and Tissue Research 363 185-194. (https://doi. org/10.1007/s00441-015-2244-2)

Suarez SS, Brockman K \& Lefebvre R 1997 Distribution of mucus and sperm in bovine oviducts after artificial insemination: the physical environment of the oviductal sperm reservoir. Biology of Reproduction 56 447-453. (https://doi.org/10.1095/biolreprod56.2.447)

Suga T \& Higaki S 1971 Studies on uterine secretions in the cow. II. Distribution of spermatozoa and seminal plasma after intra-uterine inseminations in the reproductive tract of the cow during oestrus. Bulletin of National Institute of Animal Industry 24 41-48.

Tung CK, Hu L, Fiore AG, Ardon F, Hickman DG, Gilbert RO, Suarez SS \& Wu M 2015 Microgrooves and fluid flows provide preferential passageways for sperm over pathogen Tritrichomonas foetus. PNAS 112 5431-5436. (https://doi.org/10.1073/pnas.1500541112)

Wahab M, Thompson J, Hamid B, Deen S \& Al-Azzawi F 1999 Endometrial histomorphometry of trimegestone-based sequential hormone replacement therapy: a weighted comparison with the endometrium of the natural cycle. Human Reproduction 14 2609-2618. (https://doi. org/10.1093/humrep/14.10.2609)

Wang XL, Liu HR, Tao L, Liang F, Yan L, Zhao RR, Lopez BL, Christopher TA \& Ma XL 2007 Role of iNOS-derived reactive nitrogen species and resultant nitrative stress in leukocytes-induced cardiomyocyte apoptosis after myocardial ischemia/reperfusion. Apoptosis 12 1209-1217. (https://doi.org/10.1007/s10495-007-0055-y)

Wijayagunawardane MP, Miyamoto A, Cerbito WA, Acosta TJ, Takagi M \& Sato K 1998 Local distributions of oviductal estradiol, progesterone, prostaglandins, oxytocin and endothelin-1 in the cyclic cow. Theriogenology 49 607-618. (https://doi.org/10.1016/s0093691x(98)00011-9)

Yousef MS, Marey MA, Hambruch N, Hayakawa H, Shimizu T, Hussien HA, Abdel-Razek A-RK, Pfarrer C \& Miyamoto A 2016 Sperm binding to oviduct epithelial cells enhances TGFB1 and IL10 expressions in epithelial cells as well as neutrophils in vitro: prostaglandin E2 as a main regulator of anti-inflammatory response in the bovine oviduct. PLoS ONE 11 e0162309. (https://doi.org/10.1371/journal.pone.0162309)

Zhang S, Mao W, Li Q, Gao R, Zhang Y, Gao L, Fu C, Wu J, Deng Y, Shen Y et al. 2018 Concentration effect of prostaglandin E2 on the growth factor expression and cell proliferation in bovine endometrial explants and their kinetic characteristics. Reproduction in Domestic Animals $\mathbf{5 3}$ 143-151. (https://doi.org/10.1111/rda.13083)

Zralý Z, Čanderle J, Diblíková I, Švecová D, Mašková J \& Kummer V 2003 Antisperm antibodies in cows as related to their reproductive health. Acta Veterinaria Brno 72 27-32. (https://doi.org/10.2754/avb200372010027)

Received 31 August 2019

First decision 9 October 2019

Revised manuscript received 10 November 2019

Accepted 2 December 2019 